\title{
Recurrent severe symptomatic hyponatraemia induced by low-dose oral cyclophosphamide in a patient with ANA-related vasculitis.
}

\section{Dineen $\mathrm{R}^{1}$, Pazderska $\mathrm{A}^{1}$, Mullan $\mathrm{R}^{2}$, Gibney $\mathrm{J}^{1}$, Sherlock $\mathrm{M}^{1}$}

1.Department of Endocrinology 2. Department of Rheumatology,

Adelaide and Meath Hospital incorporating the National Children's Hospital, Tallaght, Dublin, Ireland

\section{Introduction}

- Cyclophosphamide is an alkylating agent used in the treatment of malignant and autoimmune diseases.

* Severe hyponatraemia is a serious electrolyte disorder with life threatening neurological sequelae.

* It has been reported in association with a variety cytotoxic agents as vinca alkaloids, platinum compounds and alkylating agents. ${ }^{1}$

* Severe hyponatraemia after administration of low-dose cyclophosphamide therapy $(<15 \mathrm{mg} / \mathrm{kg})$ is extremely rare.

\section{Clinical Presentation}

- 61 year old lady commenced on intravenous cyclophosphamide for mononeuritis mulitplex

\section{Medical History:}

* ANA positive systemic vasculitis

* Sjogrens syndrome

* Osteoarthritis

* Multinodular Goitre

\section{First Cycle- May 2014}

Low dose cyclophosphamide, $620 \mathrm{mg}(12.5 \mathrm{mg} / \mathrm{kg})$.

Oral mesna pre \& post infusion.

Oral Ondansetron $8 \mathrm{mg}$ pre \& post infusion.

Prehydration ; $1 \mathrm{~L} 0.9 \%$ saline

$3 \mathrm{~L}$ of $\mathrm{H}_{2} \mathrm{O}$ to prevent haemorrhagic cystitis.

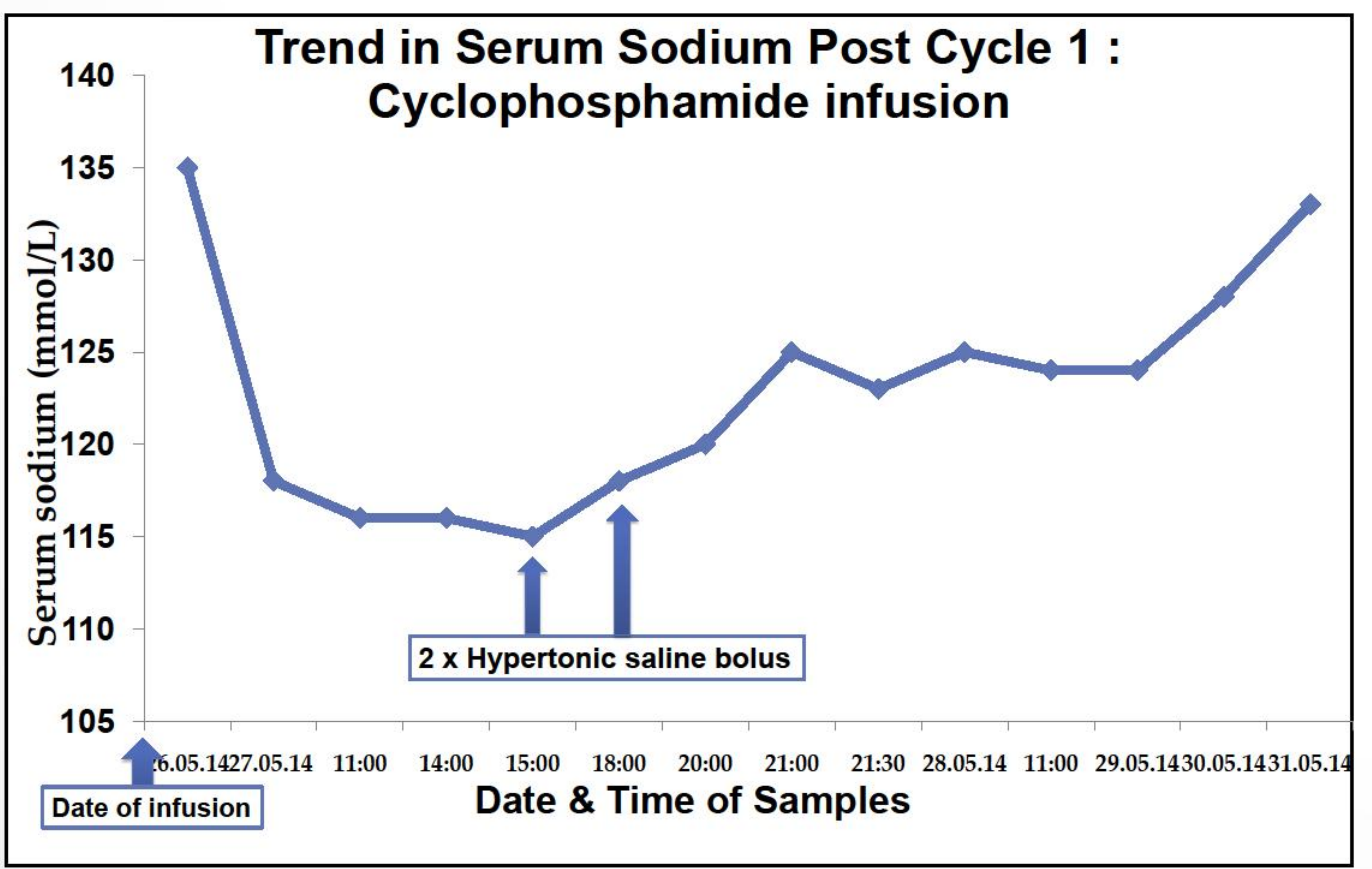

Investigations

\begin{tabular}{|l|l|}
\hline Serum Osmolality & $240 \mathrm{mOsm} / \mathrm{kg}$ \\
\hline Urine Osmolality & $347 \mathrm{mOsm} / \mathrm{kg}$ \\
\hline Urinary Sodium & $121 \mathrm{mmol} / \mathrm{L}$ \\
\hline $8 a m$ Cortisol & $800 \mathrm{nmol} / 1$ \\
\hline FT4 & $15.4 \mathrm{pmol} / 1$ \\
\hline TSH & $1.04 \mathrm{mIU} / \mathrm{L}$ \\
\hline
\end{tabular}

\section{Management}

* 24 hrs post infusion, at a serum sodium of $116 \mathrm{mmol} / \mathrm{L}$, she was nauseous, drowsy and slurring her speech.

* She was transferred to ITU

- Given stat dose of $100 \mathrm{ml}$ of $3 \%$ saline.

* Her sodium rose from $115 \mathrm{mmol} / \mathrm{L}$ to $118 \mathrm{mmol} / \mathrm{L}$.

* Persistent clinical evidence of cerebral irritation hence given another $100 \mathrm{ml}$ of $3 \%$ saline.

* Serum sodium rise $118 \mathrm{mmol} / \mathrm{l}$ to $120 \mathrm{mmol} / \mathrm{l}$.

* Within $48 \mathrm{hrs}$ her serum sodium rose to $125 \mathrm{mmol} / \mathrm{L}$

* She recovered without any neurological deficits

\section{Second Cycle- June 2014}

- Low dose cyclophosphamide

Reduced Prehydration; NO IV saline, Consumed 2L of $\mathrm{H}_{2} \mathrm{O}$.

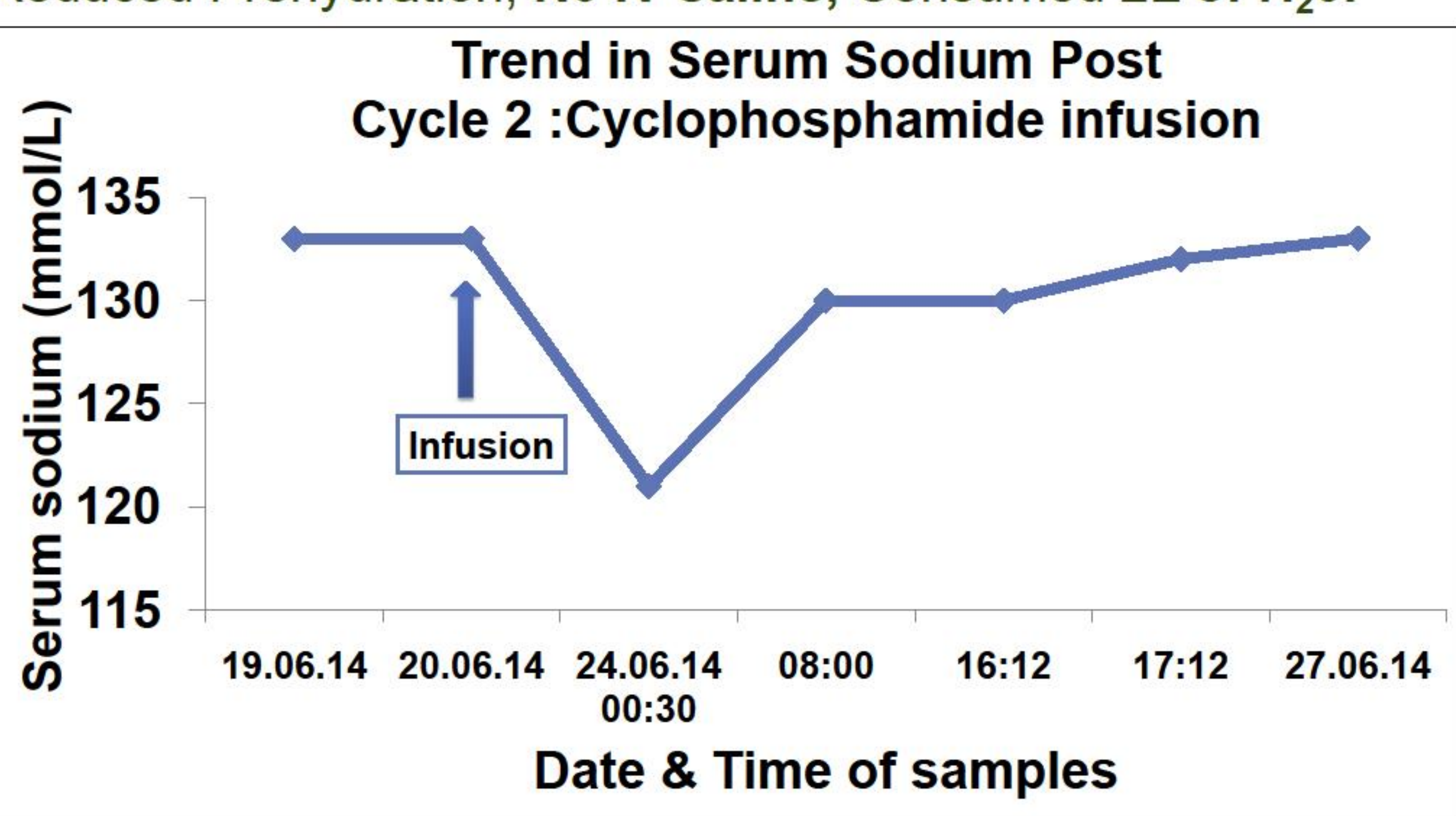

$12 \mathrm{hrs}$ post infusion, her serum sodium fell to $121 \mathrm{mmol} / /$ without neurological symptoms

Placed on fluid restriction of $1.5 \mathrm{~L}$ with gradual rise in serum sodium

\section{Third Cycle- Julv 2014}

Low dose cyclophosphamide

NO prehydration

1.5L fluid restriction

Fall in serum sodium from $135 \mathrm{mmol} / \mathrm{L}$ to $129 \mathrm{mmol} / \mathrm{l}$

No neurological symptoms

Spontaneous correction

\section{Conclusion}

* Patients receiving cyclophosphamide are at high risk of developing symptomatic hyponatraemia due to SIADH even at low doses of therapy

* Cyclophosphamide may induce SIADH, by potentiating the renal actions of $\mathrm{AVP}^{2}$.

* The combination of both increased ADH effect and excess water intake to prevent haemorrhagic cystitis can induce potentially lifethreatening hyponatraemia ${ }^{3}$

- Clinicians need to be aware of this threat when encouraging large volume prehydration and diuresis with cyclophosphamide therapy

* It is possible that pre-hydration with isotonic saline rather than oral water may minimise the incidence of this complication

\section{References}

Berghmans T. Hyponatremia related to medical anticancer treatment. Support Care Cancer. 1996 Sep:4(5):341-50 2. Lee YC, Park JS, Lee CH, et al. Hyponatraemia induced by low-dose intravenous pulse cyclophosphamide. Nephro

McCarron M. Wright GD, Roberts SD. Water intoxication after low dose cyclophosphamide. BMJ 311: 292, 1995 